\title{
KONSTRUKSI STIGMA MISTIS KOTA BANYUWANGI DALAM CERITA KKN DI DESA PENARI
}

\author{
Nurul Hasan \\ Pascasarjana UIN Sunan Kalijaga Yogyakarta \\ Email: nurulhasanalhabsy69@gmail.com
}

Diterima: 01 Juni 2020 | Direvisi: 09 Juli, 2020 | Disetujui: 19 Agustus 2020

\begin{abstract}
The title of "KKN di Desa Penari" is a viral thread (story) on twitter in mid-2019. This thread creates a new stigma for the community towards one of the city that is implicitly mentioned in the story. The problem is how the stigma is constructed by the author. This study uses an interpretive qualitative approach using the analysis method of William A. Gamson and Modigliani framing model. The results of this study indicate that the author seeks to construct a meaning through a storyline composed of texts. The story line is packaged and directed to a negative stigma by labeling Banyuwangi as a mystical city. The occurrence of KKN is implicitly located at Banyuwangi which is known as the Gandrung Dance as the city's icon, that is related behind the thread. Banyuwangi is constructed as a city with traditions and rituals, most of its residents live in forests or isolated areas and they have low economies, the forest areas are still haunted, which creates negative stigma for the city of Banyuwangi.
\end{abstract}

Keywords: Framing, Dancer, Thread, Banyuwangi

\begin{abstract}
Abstrak
KKN di Desa Penari merupakan thread (cerita) di twitter yang viral pada pertengahan tahun 2019. Thread tersebut menimbulkan stigma baru bagi masyarakat terhadap salah satu kota yang secara implisit disebutkan dalam cerita tersebut. Permasalahannya bagaimana stigma tersebut dikonstruksi oleh penulis. Penelitian ini menggunakan pendekatan kualitatif interpretatif dengan menggunakan metode analisis framing model Wiliam A. Gamson dan Modigliani. Hasil dari penelitian ini menunjukkan bahwa penulis berupaya untuk mengkonstruksi sebuah makna melalui alur cerita yang disusun dari beberapa teks. Aiur cerita dikemas dan diarahkan kepada stigma negatif dengan labeling Banyuwangi sebagai kota mistis. Terjadinya KKN secara implisit berada di Banyuwangi yang terkenal dengan Tari Gandrung sebagai ikon kota, sehingga memiliki keterkaitan erat dibalik thread tersebut. Banyuwangi dikonstruksikan sebagai kota yang lekat dengan ritual adat dan kebanyakan penduduknya bertempat tinggal di hutan atau kawasan terpencil yang berpenghasilan rendah, serta kawasan hutan belantara yang terkenal dengan keangkerannya sehingga menimbulkan stigma yang negatif bagi kota Banyuwangi.
\end{abstract}

Kata Kunci: Framing, Penari, Cerita, Banyuwangi 


\section{Pendahuluan}

Teks dibaca dan dipahami tergantung pada cara penulis menyampaikannya atau cara penulis mengemas teks sedemikian rupa sehingga dapat mengkonstruksi makna. Frame mengarahkah agar individu lain dapat dengan mudah memahami skema atau rancangan yang sengaja di bentuk sedimikian rupa oleh seorang penulis, sehingga searah dengan tujuan yang telah dibentuk sedemikian rupa. Dengan menggunakan teori framing, orang lain dapat mengidentifikasi, mempersepsi, menilai, menempatkan dan melihat suatu peristiwa dengan kacamata mereka masing-masing sehingga menciptakan paragdigma yang berbeda antara satu sama lain. Frame juga berfungsi untuk mengorganisasi pengalaman dan perilaku yang terjadi, baik perorangan maupun kelompok. Sering terjadi dalam suatu persiwa framing digunakan sebagai aspek pertimbangan dalam gerakan sosial. Para pemangku jabatan atau seorang yang memiliki hak kewenangan publik sengaja membumbui suatu peristiwa untuk membingkai untuk menimbulkan citra yang baik sehingga membentuk persepsi atau paradigma yang sama di masyarakat atau khalayak umum. Seperti yang sempat heboh di pertengahan tahun 2019 dalam thread atau cerita KKN di Desa Penari.

Thread dan tweet berantai identik dengan cuitan pengguna twitter yang memiliki pesan bersambung yang tidak cukup di jadikan satu tweet. Meski kini twitter memberikan kemudahan akses untuk membuat thread biasanya memberikan hashtag \#kultwit sebagai awalan dari thread yang dibuat, ditambah penomoran pada setiap tweet untuk mempermudah follower membaca urutan thread yang dibuat. Adanya fitur thread di twitter dan pembatasan karakter yang diperluas dari 140 menjadi 280 karakter, membuat pengguna twitter semakin gemar membuat thread dan tidak sedikit menjadi viral. Bagi pengguna twitter yang pernah mengalami kejadian mistis, biasanya dibagikan dengan thread, cerita horor biasanya muncul dengan hashtag \#memetwit, bukan hanya seram, thread kisah horor juga membuat para pembacanya penasaran.

Masyarakat Indonesia yang kaya akan beragam budaya ritualnya terutama di pulau jawa membuat ritual itu dikaitkan dengan hal yang bersifat mistis, sehingga mudah percaya akan hal yang diluar nalar manusia. Thread yang menjadi viral sejak bulan Juni 2019 silam sudah mencapai 4 juta lebih viewers ini menjadi salah satu tanda bahwa pengguna Twitter Indonesia menyukai cerita horor atau mistis. Cerita ini ditulis secara bertahap oleh pengguna akun SIMPLE MAN @simpleM81378523 di akun 
twiternya, membuat heboh para penikmat media sosial di indonesia seperti twitter, facebook, youtube, whatsapps dan lain-lain bahkan sempat menjadi trending topic di media sosial. Meningkatnya minat pembaca ini bermula ketika Raditya Dika dalam channel youtubenya mengusung sebuah topik tentang cerita horor KKN di Desa Penari, banyaknya subcriber menjadi tolak ukur banyaknya viewers yang menonton tayangan video tersebut sehingga cerita berbau mistis tersebut mudah dan cepat menyebar dikalangan penikmat youtube dan merambat ke media sosial yang lain. Cerita ini sangat menyita banyak perhatian pengguna media sosial mulai dari kalangan bawah hingga kalangan artis yang saling berdiskusi dengan argumentasinya masing-masing mengenai cerita horor tersebut.

Membumingnya cerita KKN Desa Penari, memunculkan banyak pengguna media sosial menganjurkan temannya untuk membaca cerita horor tersebut, ditandai dengan banyaknya story whatsapp yang menuliskan tentang cerita KKN Desa Penari. Dalam cerita ini ada beberapa hal yang sengaja disembunyikan oleh penulis, bahkan sang penulisnya pun merahasiakan identitasnya. Diceritakan beberapa mahasiswa tingkat akhir yang ingin menyelesaikan tugas akhir kuliahnya dengan melaksanakan Kuliah Kerja Nyata di suatu desa di Jawa Timur dengan berinisial desa W, mahasiswa ini terdiri dari 6 orang masing-masing dengan nama yang di samarkan, mereka juga merupakan mahasiswa dari salah satu kampus elit yang juga disamarkan dan diganti dengan label kota $\mathrm{S}$, sebelum sampai di kota tujuan yang berinisial $\mathrm{B}$, di perjalanan mereka melewati kota dengan inisial huruf $\mathbf{J}$ dan selama diperjalanan ditulis bahwa ada sosok penari yang menyambut kedatangan mereka. Penulis mengangkat nilai tradisional/budaya asli yang menggiring pembaca kepada sosok penari yang menjadi icon kota Banyuwangi, realitas kehidupan yang terjadi kemudian direkonstruksi kembali untuk melahirkan citra penari sebagai ikon kota yang berbau mistis, aktivitas ritual yang terus dijaga hingga sampai saat ini.

Cerita ini bisa digunakan untuk mengungkap bagaimana pemikiran dan ideologi yang disampaikan oleh penulis dalam memframing suatu thread atau cerita. Melalui cerita ini penulis menyampaikan pesan kepada khalayak dengan gaya penceritaan atau bahasa yang menarik untuk membuat pembaca penasaran. Penulis dapat mengarahkan pembaca ke sudut pandang tertentu dalam memandang atau meyakini suatu hal melalui framing sehingga pembaca secara sadar atau tidak sadar tergiring saat mengikuti aliran 
cerita dalam tulisannya. Cerita ini memiliki banyak unsur yang sengaja dirahasiakan si penulis, namun penulis sengaja menggunakan inisial membuat para pembaca tergiring dengan inisial cerita KKN Desa Penari tersebut. Sehubungan dengan hal ini di atas maka penelitian ini di maksudkan untuk mengungkap bagaimana pemikiran dan ideologi yang disampaikan oleh penulis dalam memframing suatu thread atau cerita yang di gunakan oleh pengarang di dalam cerita KKN Desa Penari. Rekonstruksi realitas tersebut akan dianalisis dengan menggunakan analisis framing model Gamson dan Modigliani untuk mengungkapkan makna di balik penggunaan teks/bahasa pada cerita tersebut.

\section{Metodologi Penelitian}

Metode penelitian yang digunakan yaitu dengan menggunakan pedekatan kualitatif, sedangkan metodenya menggunakan analisis framing model Gamson dan Modigliani, dengan metode ini penliti dapat mendeskripsikan dengan subjektifitas (interpretatif) penulis. Dalam penlitian ini, segala hal yang disajikan oleh penliti merupakan analisis yang sesuai dengan pemahaman penliti, sehingga hasil yang dideskripsikan maupun hasil yang didapatkan tidak akan sama dengan paradigma orang lain dalam memahami cerita ini walaupun sama dalam objek kajiannya, sehingga menimbulkan pandangan yang berbeda-beda dengan hasil penelitian yang lainnya. (Sugiono, 2011, hal. 11).

\section{Kajian Teori}

\section{Analisis Framing}

Analisis framing merupakan salah satu alternatif untuk melihat fakta tersembunyi dibalik suatu peristiwa, sehingga dapat menumculkan paradigma tertentu dalam melihat wacana media massa. Dengan menggunakan analisis framing suatu wacana akan mudah dimaknai lebih-lebih yang berkaitan dengan konteks sosial dan budaya. Dalam suatu berita pastinya ada ideologi yang disematkan oleh penulis berita sehingga ada proses maupun mekanisme seperti apa atau bagaimana proses media dibangun, diproduksi, dipertahankan, dibumbui, dan menggeser ideologi yang lain. Dengan menggunakan analisis ini kita dapat melihat siapa yang menjadi dalang dan siapa yang menjadi aktor dibalik berita yang diproduksi, sehingga dapat disimpulkan 
akan ada pihak yang diuntungkan maupun dirugikan. (Eriyanto, 2012, hal. xv) Analisis framing juga dapat dikatakan sebagai metode atau cara memahami realitas yang terjadi dalam suatu wacana, berita maupun peristiwa yang terjadi baik individu maupun kelompok terntentu. Berita tersebut dikemas sedemikian rupa melalui proses konstruksi oleh media. Secara efektifnya framing digunakan untuk menonjolkan atau memfokuskan suatu berita dan menenggelamkan atau meruntuhkan berita yang lain. Bagaimana media mengkonstruksi realitas, jadi dalam analisis framing ini tidak memfokuskan mengenai siapa yang benar maupun salah tetapi bagaimana media mengemas dan menyajikannya terhadap khalayak luas. (Eriyanto, 2012, hal. 7)

Menurut Gamson dan Modigliani frame memiliki struktur internal, sehingga didalam suatu berita ada titik pusat didalamnya yang menjadi ide atau gagasan, sehingga suatu peristiwa terlihat relevan dan dapat menonjolkan isu tertentu. Framing menggambarkan bagaimana cara seseorang menulis ide atau gagasan yang sistematis sehingga terbentuk konstruksi makna yang sedemikian rupa untuk dikaitkan dengan konteks suatu wacana yang telah dibangun oleh penulis berita. Ghamson memandang wacana media terbentuk dari beberapa kemasan dengan mengkonstruksi realitas yang terjadi. Kemasan adalah struktur atau skema kognisi yang digunakan oleh individu maupun kelompuk untuk mengkonstruksi berita yang dia tulis, dan memaknai peristiwa yang terjadi. Framing merupakan pendekatan untuk memahami bagaimana paradigma atau sudut pandang wartawan dalam memilah isu dan mengkostruksi berita. Dengan paridma atau sudut pandang tertentu dapat memilah berita mana yang akan ditekankan atau ditonjolan dan berita mana yang akan di runtuhkan, dan akan diarahkan kemanakah konstruksi tersebut. (Eriyanto, 2012, hal. 261)

Peneliti memakai model Gamson dan Modigliani, yaitu model dengan berdasarkan pendekatan konstruksionis dengan memandang repsesentasi media berbentuk realitas sosial. Terbentuk dari beberapa frame yang mendukung suatu makna realitas yang terjadi. Bingkai atau frame merupakan kumpulan ide yang mengindikasikan wacana apa yang diperbincangkan dan berita apa yang pantas untuk dimuat. (Eriyanto, 2012, hal. 224) Frame mempunyai dua struktur, pertama yakni struktur core frama merupakan gagasan sentral, yang kedua condensing siymbol adalah hasil pecermatan interaksi simbolik. Skema dari analis framing Gamson dan Modigliani dapat dilihat dibawah ini:: 


\begin{tabular}{|l|l|}
\hline Media Framing \\
\hline Pernagkat Framing \\
\hline $\begin{array}{l}\text { Metafora/Kiasan } \\
\text { Contoh } \\
\text { Slogan } \\
\text { Penggambaran Isu } \\
\text { Gambar Visual }\end{array}$ \\
\hline
\end{tabular}

Sumber: (Sobur, 2012, hal. 117)

Gamson berpendapat bahwa framing merupakan seperangkat ide atau gagasan yang esensial pada saat individu atau kelompok memaknai dan memahami realitas yang terjadi. Gagasan atau ide esensial ini akan membutuhkan perangkat wacana lain sebagai pendukungnya. (Eriyanto, 2012, hal. 226) Perangkat dalam teks berita terbagi menjadi dua yang pertama yaitu perangkat framing adalah perangkat yang berkaitan dan berhubungan langsung dengan ide sentral atau esensial yang ditonjolkan dalam teks berita, yang kedua yaitu perangkat penalaran, perangkat ini berkaitan dengan koleksi daun koherensi teks yang merujuk pada ide yang spesifik.

Dua perangkat framing juga dijelaskan oleh eriyanto mengenai dua perangkat framing model Gamson dan Modigliani di bawah ini:

\begin{tabular}{|l|l|}
\hline $\begin{array}{l}\text { Bingkai/Kemasan } \\
\text { Pusat pengorganisasian Ide sentral untuk memahami peristiwa yang relevan, } \\
\text { menyarankan apa yang menjadi permasalahan. }\end{array}$ \\
\hline Perangkat Framing & Perangkat Penalaran \\
\hline $\begin{array}{l}\text { Metafora/Kiasan } \\
\text { Pengandaian atau perumpamaan }\end{array}$ & $\begin{array}{l}\text { Analisis Kausal } \\
\text { Analisis hukum sebab akibat atau } \\
\text { kausal }\end{array}$ \\
\hline $\begin{array}{l}\text { Slogan } \\
\text { Frase yang menonjol, kontras, menarik } \\
\text { dalam wacana berita. Dalam bentuk } \\
\text { slogan atau jargon }\end{array}$ & Pembenaran Isu \\
\hline
\end{tabular}




\begin{tabular}{|l|l|}
\hline $\begin{array}{l}\text { Contoh } \\
\text { Menghubungkan frame dengan contoh } \\
\text { realitas yang terjadi }\end{array}$ & $\begin{array}{l}\text { Konsekuensi } \\
\text { Konsekuensi atau efek framing yang } \\
\text { ditimbulkan. }\end{array}$ \\
\hline $\begin{array}{l}\text { Pelukisan atau Penggambaran Isu } \\
\text { Pelukisan atau penggambaran isu yang } \\
\text { berkarakter konotatif. Biasanya } \\
\text { berbentuk leksikon, kosa kata untuk } \\
\text { menggambarkan sesuatu. } \\
\text { umumnya berupa kosa kata, leksikon } \\
\text { untuk melabeli sesuatu. }\end{array}$ & \\
\hline $\begin{array}{l}\text { Gambar Visual } \\
\text { Berupa gambar, citra, grafik sebagai } \\
\text { pendukung pesan yang dibentuk. } \\
\text { Perangkat penalaran }\end{array}$ & \\
\hline
\end{tabular}

Sumber: (Eriyanto, 2012, hal. 225)

Dari kedelapan unsur framing di atas dapat dijabarkan atau dijelaskan dibawah ini:

1. Metafora atau kiasan merupakan merelasikan dua fakta melalui analogi atau memakai kiasan sehingga dapat memindahkan makna aslinya. Kata yang dianalogikan atau dikiaskan biasanya seperti kata sebagai, umpama, ibarat, baik, laksana dan lain-lain. Metafora bisa dikatakan suatu kata yang memiki dua peran atau dua arti sebagai ekspresi mental dan perangkat diskursif. Dan memaksa realitas teks agar membuat sense tertentu.

2. Slogan atau jargon merupakan istilah atau bentuk kata yang mewakili sebuah fakta yang merujuk pada semangat sosial atau pemikiran demi menambah kekuatan tertentu dalam berdialog maupun teks.

3. Contoh merupakan cara menguraikan atau membingkai fakta secara mendalam sehingga menjadi makna yang memiliki arti lebih sehingga dapat dijadikan rujukan dan mampu memjadi satu kesatuan dengan wacana berita yang lain. Sehingga isu yang dikonstruksi akan menjadi berita yang valid

4. Penggambaran isu merupakan penggambaran dengan menggunakan kalimat konotatif, leksikon, istilah kata untuk melabeli realitas yang terjadi sehingga masyarakat terpengaruh kepada citra tertentu. 
5. Gambar visual merupakan perangkat yang berbentuk gambar, grafik, diagram, tabel, dan lain-lain. Fungsinya sebagai pelengkap atau pendukung teks yang ditekankan atau ditonjolkan.

6. Analisis kausal merupakan pemberatan isu dengan cara menghubungkan sutu realitas yang dirasa dapat menjadi sebab timbulnya hal yang lain. Berdasarkan hubungan kausal yang dijabarkan sehingga membentuk penyimpulan fakta yang sengaja dibenarkan.

7. Pembentukan Prinsip merupakan cara memberikan argumentasis mengenai kebenaran suatu isu dengan menggunakan klaim moral, logika pemikiran dan prinsip mengkonstruksi realitas.

8. Konsekuensi, konsekuensi atau efek yang bakal didapat pada saat akhir dialog atau teks mengenai isu yang dikonstruksi oleh media. (Eriyanto, 2012, hal. 225)

\section{Thread Twitter}

Media twitter merupakan media sosial yang dapat berinteraksi dengan sesama penggunanya melaui cuitan atau tweet, tetapi memiliki keterbatasan penlisan yaitu hanya 140 kata. Penggunaan twitter bisa berbentuk tulisan maupun foto. Dengan menggunakan twitter penggunanya bisa saling berinteraksi antara satu sama lain dengan berbagi pengalaman maupun keluh kesah yang mereka pikirkan. Bisa juga digunakan untuk saling memberikan suatu kabar atau berita tentang peristiwa yang terjadi disekitar, serta aktivitas yang dilakukan dalam melakukan kegiatan sehari-hari. Twitter mempunyai kesamaan sekaligus perbedaan dengan facebook, persamaannya yaitu facebook dan twiter sama-sama media sosial yang saling menghubungkan antara satu sama lain dengan penggunanya. Perbedaanya media twitter lebih sedikit dalam memberikan akses untuk menulis sebuah tulisan sedangkan facebook dapat menulis suatu kata hingga melebihi 140 kata. Namun keterbatasan kata bisa disambung atau dijadikan tweet berantai yang dikenal dengan istilah thread.

Twitter didirikan oleh Jack Dorsey pada Maret 2006. Twitter sebagai salah satu dari 5 besar jerjaring sosial yang sering dikunjungi oleh pengguna media sosial. Sehingga pada tahun 2012 popularitas jejaring sosial twitter ini sangat meningkat, dan sudah mencapai 150.000 .000 pengguna. Dan menjadi 600 juta pengguna pada tahun 2014. Dan pada tahun 2020 Indonesia menjadi peringkat ketiga di Asia sebagai 
pengguna media sosial twitter yaitu dengan jumlah 44,6 juta pengguna. Seperti yang dilansir dilaman kominfo.go.id.

Jack Dorsey selaku pendiri twitter merupakan mahasiswa di New York University. Pada mulanya twitter dibuat hanya untuk memfasilitasi karyawan Ordeo. Namun setelah berkembangnya twitter pada tahun 2006 di bulan Juli akhirnya bisa dinikmati oleh masyarakat umum. Dan setelah satu tahun kemudian disetiap harinya sudah mencapai lebih dari 400rb tweet, dan melebihi 75 ribu aplikasi di twitter pada tahun 2007. Seiring dengan berjalannya waktu twitter semakin dikenal oleh pengguna media sosial dan menjadi trending. Pada tahun 2014 twitter sudah memperbaharui tampilannya dan mulai bekerja sama dengan pihak Bing, Google, Yandex dan lain-lain. Mulai dari kalangan bawah hingga kalangan atas rata-rata sudah memiliki akun twitter, tidak menutup kemungkinan jika twitter menjadi wadah untuk berinteraksi antara pengguna satu dengan pengguna yang lainnya. (Rahman, 2016, hal. 14-17)

\section{Penari}

Penari yaitu seseorang yang menari atau melakukan gerakan tarian. Penari merupakan individu atau kelompok yang mempunyai bakat atau keterampilan khusus melalukan suatu gerakan tarian sehingga terhilat indah dan memiliki nilai yang bermutu tinggi. Penari jawa merupakan seseorang yang melakukan gerakan tari tradisional jawa. (Kussudiardja, 1992, hal. 27) Sedangkan tarian tradisional yaitu gerakan tari atau tata cara menari yang dilakukan oleh suatu etnik atau suku yang diwariskan secara turun temurun sehingga menjadikannya suatu budaya yang terus dilestarikan hingga saat ini. Penari jawa diharuskan agar memahami konsep wirama, wirasa dan wiraga. Sehingga memiliki kekuatan rasa dan penjiwaan yang lebih mendalam yaitu aspek wirasa, penari diharuskan bisa mengontrol emosinya supaya mampu mengendalikan gerakan tariannya dan menyesuaikan dengan alunan tabuhan irama yang mengliringinya. (Jazuli, 1994, hal. 38)

Ekspresi manusia bisa dituangkan dalam bentuk tari yang bersifat estetis dan merupakan bagian yang tak dapat dipisahkan dari realitas yang terjadi di masyarakat berbudaya seperti suku jawa dan lain-lain sehingga memunculkan makna yang berbedabeda dengan suku yang lainnya. (Hadi, 2007, hal. 89) Suatu tarian terdiri dari beberapa aspek-aspek yang mendukungnya yaitu : irama, gerak, bentuk, tubuh, jiwa, tujuan dan 
maksud dari gerakan tari tersebut. (Jazuli, 1994, hal. 39) Dilingkungan masyarakat indonesia keberadaan seni tari dapat dilihat dari bentuk yang berbeda yaitu komunitas atau suku yang ada diindonesia dan ekspresi individual yang tercipta dari diri sendiri sebagai karya seni untuk diri sendiri maupun kekayaan individual. (Sumaryono, 2003, hal. 3)

\section{Tari Gandrung}

Kota Banyuwangi merupakan kota yang terkenal dengan tariannya Gandrung, kata gandrung secara sederhana dapat dimaknai cinta tergila-gila. Menurut Kamus Besar Bahasa Indonesia (KBBI), kata Gandrung berarti sangat rindu; tergila-gila karena asmara. Menggandrungi: amat mencintai ; tergila-gila pada seorang gadis cantik, amat senang bersama gadis itu. Menurut Dariharto (2009) Awal mula tari Gandrung pada masa Majapahit melakukan penyelenggaraan upacara di istananya, sehingga kerap dipentaskan sebuah tarian khas istana yang dikenal dengan istilah Juru I Angin, yaitu penari wanita yang sambil menyanyi sehingga terlihat menarik. penari itu diiringi oleh Buyut, yaitu lelaki tua yang menjadi sebagai punakawan penari juru I angin. Tari gandrung berupa gerakan tari yang mengandung nilai magis, religius serta bersifat yang melahirkan batas-batas kaidah kesopanan yang sesuai dengan kepribadian dan watak khas masyarakat Banyuwangi. Dewasa ini tari gandrung Banyuwangi bersifat hiburan yang berupa tari dengan gendhing Banyuwangi, akan tetapi dalam tari Gandrung masih kelihatan sifat aslinya sebagai tari pemujaan dan banyak mempengaruhi para seniman daerah Banyuwangi dalam menciptakan tarian jenis gandrung baru. Pada tari Gandrung Banyuwangi unsur keistanaanpun masih dapat dilihat, Yaitu dari segi busananya, tata rias serta cara bernyanyinya yaitu cara membawakan lagu yang berkesan memberikan gambaran seperti suasana zaman kerajaan Blambangan dahulu kala. (Dariharto, 2009, hal. 5)

Sejarah mencatat, pada awal mulanya tarian Gandrung dibawakan oleh lelaki yang berperawakan layaknya penari perempuan (Scholte 1927). Seiring berjalannya waktu penari laki-laki berganti menjadi penari yang diperankan oleh wanita sejak era 1980-an, kemungkinan hal ini terjadi lantaran masuknya agama Islam yang didalam ajarannya melarang laki-laki berdandan layaknya perempuan. Pemeran tari laki-laki mulai digantikan perempuan selepas meninggalnya Marsan selaku penari lelaki terakhir. 
Beberapa sumber menyebutkan lahirnya tari Gandrung bertujuan menghibur para pembabat hutan, serta sebagai pengiring upacara meminta keselamatan, agar pembabatan hutan yang dirasa angker berjalan dengan lancar.

Dalam sejarah penari Gandrung wanita mulanya dikenal dengan nama Gandrung Semi, yaitu tepatnya pada tahun 1895, Gandrung Semi ini diperankan oleh anak kecil yang berusia sepuluh tahun. Banyak cerita dimasyarakat yang mengisahkan bahwa Semi seorang anak kecil tersebut mengalami sakit parah namun tak kunjung sembuh, berbagai cara telah ditempuh hingga menggunakan cara pergi ke dukun namun hal tersebut berujung sia-sia. Sehingga ibunya bernazar jika anaknya sembuh akan dijadikan seblang, ternyata setelah itu semi menjadi sembuh dan sesuai dengan nazar ibunya ia dijadikan seblang. Sejak itulah tari Gandrung mulai ditarikan oleh seorang perumpuan yaitu semi serta adik-adik perempuannya. Semi menyematkan gandrung di setiap pementasannya.

Tari Gandrung semakin lama terus berkembang dan menjadi ikon atau maskot kota Banyuwangi. Awal mulanya tari Gandrung hanya boleh dilakukan oleh keturunan Gandrung, tetapi pada saat tahun 1970-an banyak gadis-gadis yang mempelajari tarian Gandrung dan menjadikan ladang mata pencahariannya walaupun ia bukan keturunan seorang Gandrung. Hal ini juga dilakukan demi mempertahankan budaya yang terus digerus zaman, dan dikhawatirkan seni tari ini akan hilang jika tidak dilestarikan.Pada tanggal 31 desember 2002, Bupati Banyuwangi mengeluarkan surat keputusan nomor 173 mengenai tari gandrung, dimana tari gandrung ditetapkan sebagai icon kota Banyuwangi. Sehingga seni budaya banyuwangi banyak dipengaruhi oleh tari Gandrung, baik acara apapun yang digelar pasti tidak luput dari pementasan tari Gandrung sebagai tarian penyambut tamu di banyuwangi. (Scholte, 1972, hal. 144)

\section{Pembahasan}

Sesudah pemaparan konstruksi realitas KKN di Desa Penari, bisa diambil kesimpulan bahwa perspektif seseorang dalam memaknai realitas sosial yang terjadi berdasarkan konstruksi realitas yang ia pahami. Simple Man sangat paham mengenai makna penari yang menjadi icon kota Banyuwangi, tetapi citra penari yang dikonstruksi oleh Simple Man malah dinilai mengarah kepada citra yang buruk dimana Simple Man dalam cerita ini mengarahkan kepada beberapa topik. Dimulai dengan mengarahkan 
pembaca mengasumsikan tempat KKN di kota Banyuwangi, yang kedua tari Gandrung merupakan tari sambutan kepada tamu yang identik sebagai icon Banyuwangi, yang ketiga pelestarian budaya dan ritual yang mistis, dan yang keempat hutan yang masih angker, dan penduduk desa yang masih tradisional dengan penghasilaan ekonomi yang rendah. Dalam cerita ini Simple Man berpandangan bahwa kota yang terletak di ujung timur pulau Jawa yaitu kota Banyuwangi, memiliki banyak hutan belantara yang masih alami dengan pepohonan yang lebat karena kaya akan hutan yang masih alami, kota yang masih menjaga budaya dan kental dengan ritual mistisnya serta terkenal dengan tarian gandrung yang menjadi ikon Banyuwangi.

Dalam cerita penulis sengaja merahasiakan identitas dirinya, begitu juga tempat KKN ini dilaksanakan, menurut penulis cerita ini sengaja dirahasiakan karena ingin menjaga identitas pelaku namun penulis sengaja mengarahkan pembaca dengan menggunakan simbol atau huruf untuk dijadikan pijakan/patokan dalam mengarahkan pembaca dalam memahami kota asal tujuan atau tempat dimana KKN itu berlangsung. Seperti yang tertulis dalam cerita penari, namun penulis juga tidak menutup kemungkinan pembaca familiar dengan beberapa tempat meski disamarkan.

"Jadi buat teman-teman yang membaca cerita ini, yang mungkin tahu, atau merasa familiar dengan beberapa tempat yang meski di samarkan ini, di mohon, untuk diam saja, atau merahasiakan semuanya".

\section{https:/twitter.com/simplem81378523}

"Sesuai apa yang Nur katakan. Mobil berhenti di jalur masuk hutan D, menempuh perjalanan 4 sampai 5 jam dari kota $S$, tanpa terasa hari sudah mulai petang, di tambah area dekat dengan hutan, membuat pandangan mata terbatas.

\section{https://witter.com/simplem81378523}

"Cuk. sepedaan tah" kata Wahyu, spontan, saat itu ada yang aneh entah disengaja atau tidak, ucapan yang di anggap biasa di kota $\mathrm{S}$, di tanggapi lain oleh lelaki-lelaki itu, wajahnya tampak tidak suka, dan sinis tajam melihat wahyu".

\section{https:/twitter.com/simplem81378523}

Dalam kutipan ini dijelaskan jika perjalanan yang ditempuh dari kota $\mathrm{S}$ yaitu sekitar 4-5 jam dimana waktu ini sesuai dengan waktu tempuh yang dibutuhkan dari 
kota Surabaya ke kota Banyuwangi. Ditambah dengan dialek kota Surabaya yang identik dengan kata "cuk" ini semakin memperjelas kota dimana tempat mereka kuliah ada di kota Surabaya.

"Benar saja. perasaan tidak enak itu, terus bertambah seiring mobil terus melaju, salah satu pertanda buruk itu adalah ketika, sebelum memasuki kota $\mathrm{J}$, dimana tujuanya kota B, Nur melihat kakek-kakek yang meminta uang di persimpangan, ia seakan melihat Nur. tatapanya, prihatin".

\section{https://twitter.com/simplem81378523}

Pada kutipan ini semakin diperjelas dengan menggunakan hurup J yang menjadi huruf awal dari kota Jember, dimana kota ini terletak di sebelah barat kota Banyuwangi, dan kota ini bakal dilewati ketika akan menempuh perjalanan ke kota Banyuwangi. Dari beberapa kutipan diatas sangatlah jelas bahwa penulis sengaja merahasiakan tempat berlangsungnya KKN tersebut, namun penulis juga memberikan simbol atau huruf yang mewakili nama kota tersebut. Kesimpulan dari penjelasan tujuan yang menjadi tempat KKN di desa penari yaitu kota Banyuwangi, yang identik dengan kota tari yaitu tari Gandrung yang menjadi ikon kota Banyuwangi.

Tari Gandrung merupakan ikon banyuwangi yang sudah familiar di masyarakat, tari ini dilakukan untuk acara penyambutan tamu maupun acara slametan yang sering dilaksanakan di kota Banyuwangi. Diperbatasan kota Banyuwangi terdapat patung Gandrung dimana patung tersebut sebagai simbol perbatasan yang membatasi kota Jember dan kota Banyuwangi. Dalam cerita ini dijelaskan ketika mulai memasuki hutan ada sosok penari yang menyambut kedatangan mereka, secara tidak langsung ini menggambarkan bahwa ketika memasuki perbatasan kota Banyuwangi mereka mendapat sambutan berupa tarian yaitu Tari Gandrung.

"Nur, melihat sesosok, wanita. ia sedang menari di atas batu kilatan matanya tajam, dengan paras elok nan cantik, si Wanita, tersenyum menyambut tamu yang sudah ia tunggu".

https://witter.com/simplem81378523 
Disini menjelaskan mereka disambut oleh tarian, sebelum memasuki tempat $\mathrm{KKN}$, di desa penari. Tari gandrung yang menjadi ikon Banyuwangi sekaligus menjadi tari sambutan untuk tamu yang datang.

Pada topik kedua penulis mengarahkan pembaca untuk mengenal lebih dalam kota Banyuwangi, dimana ritual dan kepercayaan masyarakatnya masih memegang teguh budaya asli Banyuwangi.

"Di setiap Nisan, di tutup oleh kain hitam. pemakamanya sendiri, di kelilingi pohon beringin, dan di setiap pohon beringin, ada batu besar di sampingnya, disana, ada lengkap, sesajen di depanya".

\section{https://twitter.com/simplem81378523}

Menggambarkan masyarakat di desa ini sangat kental dengan ritual atau kepercayaan mistis dimana itu identik dengan kain hitam dan sesajen sebagai sesembahan.

"Tidak ada satupun rumah yang memiliki kamar mandi adalah karena sulitnya akses air, 6 lelaki paruh baya dengan motor butut, samping sungai, ada sebuah bilik dengan kendi besar di dalamnya, disana, bisa di gunakan untuk mandi, Listrik di desa ini menggunakan tenaga Genset, jadi ketika jam menunjukkan pukul 9 , lampu sudah mati, di ganti dengan petromak. kebanyakan anak-anak yang sudah akil baligh pasti pergi merantau".

\section{https://witter.com/simplem81378523}

Dalam cerita ini juga menggambarkan bahwa desa ini memiliki ekonomi yang rendah, dimana sumber penerangan masih menggunakan genset dan juga kebanyakan setiap rumah masih beralaskan tanah dan model rumah memiliki kesamaan yaitu hanya bagian depannya saja yang menggunakan gedung. Masyarakatnya yang menggunakan motor butut serta fasilitas umum yang masih menggunakan fasilitas alami yaitu dengan cara menggambil air disungai serta melakukan aktifitas lainnya bergantung kepada sungai. Ini menandakan bahwa didesa ini sangat terpencil.

Pada topik 3 penulis mengarahkan pembaca agar memahami bahwa kota di ujung timur pulau Jawa merupakan hutan yang angker yang didukung oleh beberpa 
pendapat yang menjelaskan bahwa hutan ini angker dan berbahaya bagi manusia seperti yang dijelaskan di bawah ini.

"Malam semakin gelap, dan hutan semakin sunyi sepi, namun, kata orang, dimana sunyi dan sepi di temui, disana, rahasia di jaga rapat-rapat. jauh hari sebelum malam pembekalan, Widya berpamitan kepada orangtuanya tentang progress $\mathrm{KKN}$ yang wajib ia tempuh, keika orangtua Widya bertanya kemana Projek KKN mereka, terlihat wajah tidak suka dari raut ibunya. "gak onok nggon liyo, lapo kudu gok Kota B," (apa gak ada tempat lain, kenapa harus kota B) wajah ibunya menegang. "nggok kununggone Alas tok, ra umum di nggoni gawe menungso" (disana tempatnya bukanya hutan semua, tidak bagus ditinggali oleh manusia). "Banyu semilir mlayu nang etan," (air selalu mengalir ke arah timur) yang memiliki makna, bahwa timur adalah tempat dimana semua di kumpulkan menjadi satu, antara yang buruk dan yang paling buruk, dan kini, Widya harus tinggal di hutan paling timur (sing paling penting, nek sampeyan krungu suoro ra onok wujud'e, tetep lanjut, bade sampeyan sampe di gawe ciloko, nek isok lanjut, lanjut ae, ra usah di urus mas, sampeyan percoyo ae, dungo nggih" (yang paling penting, jika kalian dengar suara tanpa wujud, tetap lanjut saja)".

\section{https://witter.com/simplem81378523}

Kutipan diatas menjelaskan mulai dari pendapat penulis, ibu Widya hingga penjual cilok menjelaskan bahwa tempat yang mereka tempati adalah tempat yang tidak cocok dihuni manusia, dan juga tempat yang terkenal angker yang sudah familiar ditelinga masyarakat. Jadi disini penulis sengaja menekankan secara tidak langsung bahwa Kota yang terletak di ujung timur pulau jawa yaitu kota banyuwangi, memiliki kekayaan akan hutan yang masih alami namun juga menyimpan mistis, terkenal dengan santet dan keangkerannya. Ditambah dengan beberapa penampakan atau sosok hantu yang tergambarkan dalam cerita ini identik dengan kota banyuwangi seperti yang ada dalam kutipan dibawah ini.

\footnotetext{
"Ia melihat wanita itu di dalam pawon rumah, ia sedang menari dengan anggun, sesaat sebelum ia melihat wajahnya, si bapak kaget setengah mati, karena di balik sirat wajah wanita yang di sangka terlihat jelita itu, rupanya polos, rata tak ada bentuk" .
}

"Nur, terdiam melihat sebuah batu yang di tutup oleh kain merah. di bawahnya, ada sesajian lengkap dengan bau kemenyan. diatasnya, berdiri sosok hitam, dengan mata picing, menyala merah. meski hari siang bolong, Nur bisa melihat, kulitnya yang di tutup oleh bulu, serta tanduk kerbau, mata mereka saling melihat satu sama lain". 
Dalam kutipan ini menjelaskan beberapa penampakan yang terlihat atau digambarkan oleh penulis yaitu mengenai sosok penari dan hitam bertanduk dimana ini identik dengan kota banyuwangi yang terkenal dengan penari dan kebo-keboan dimana dua tarian ini sering dilakukan ditampilkan dalam suatu acara atau festival di Banyuwangi. Namun disini penulis menggambarkan dua hal ini sebagai hal yang mistis dan mengerikan, begitu pula sejak awal citra yang dibangun oleh penulis secara tidak langsung menggambarkan kota Banyuwangi sebagai kota yang banyak akan hutannya yang terkenal dengan budaya dan ritual serta keangkerannya. Sehingga memunculkan citra yang buruk bagi masyarakat kota Banyuwangi.

"Sejak awal, mbak Nur tidak begitu tertarik dengan unsur seram dalam ceritanya, ia ingin menyampaikan pesan yang terkandung di dalamnya, agar siapapun kita, tetap menjaga tata krama, ini bukan tentang, hal yang sepele, siapapun kamu, dimanapun kamu berada, sekali lagi, jaga sikap dan prilaku karena sesungguhnya sebagai tamu, selayaknya tetap bersiteguh pada warisan pendahulu kita yang mengutamakan sopan santun terhadap tuan rumah".

\section{https://twitter.com/simplem81378523}

\section{Kesimpulan}

Dari paparan cerita di atas, penulis dapat mengambil kesimpulan bahwa cerita atau thread $\mathrm{KKN}$ di desa penari terdapat beberapa struktur teks yang menunjukkan makna-makna secara implisit. Hasil analisis framing Willian A Gamson menunjukkan bahwa penulis berupaya untuk mengkonstruksi sebuah makna-makna melalui alur cerita yang disusun dari beberapa teks. Alur cerita dikemas dan diarahkan kepada stigma negatif dengan labeling Banyuwangi kota mistis.

Dalam cerita tersebut penulis mengalokasikan tempat terjadinya KKN secara implisit berada di kota Banyuwangi. Kota tersebut dikenal dengan tari gandrung sebagai icon kotanya, penulis mengkonstruksi bahwa masyarakat di kota tersebut tetap menjaga tradisi dan ritual adat, kebanyakan penduduknya bertempat tinggal di hutan atau kawasan terpencil dan berpenghasilan rendah, serta kebanyakan hutan belantara yang masih alami namun terkenal dengan keangkerannya sehingga mengkonstruksi nilai yang negatif bagi kota Banyuwangi. 


\section{Referensi}

Dariharto. (2009). Kesenian Gandrung Banyuwangi. Banyuwangi: Dinas Kebudayaan dan Parawisata Kota Banyuwangi.

Eriyanto. (2012). Analisis Framing. Yogyakarta: LKIS Group.

Hadi, S. (2007). Kajian Tari Teks dan Konteks. Yogyakarta: Pustaka Book Publisher.

Jazuli, M. (1994). Telaah Teoritis Seni Tari. Semarang: IKIP Semarang.

Kussudiardja, B. (1992). Dari Klasik Hingga Kontemporer. Yogyakarta: Padepokan Press.

Rahman, T. (2016). Pengertian Media Sosial Twitter. Bandung: Jaya Pustaka.

Scholte, J. (1972). Gandroeng Van Banjoewangie. Banyuwangi: Djawa.

Sobur, A. (2012). Analisis Teks Media: Suatu Pengantar Untuk Analisis Wacana, Analisis Semiotik dan Analisis Framing. Bandung: PT Remaja Rosda Karya.

Sugiono. (2011). Metode Penelitian Kuantitatif Kualitatif dan $R \&$ D. Bandung: Alfabeta.

Sumaryono. (2003). Restorasi Seni Tari dan Transformasi Budaya. Yogyakarta: Lembaga Kajian Pendidikan dan Humaniora Indonesia.

Simpleman. 2019. KKN Di Desa Penari. Jakarta Selatan : PT. Bukune Kreatif Citra.

Anggarani, Widya Ayu dan Yohanis F. L Kahija. 2016. Makna Menjadi Penari Jawa Sebuah Interpretative Phenomenological Analysis. Jurnal Empati.

Ariyani, Isma. 2014. Representasi Nilai Siri' Pada Sosok Zainuddin Dalam Novel Tenggelamnya Kapal Van Der Wijck (Analisis Framing Novel). Skripsi Fakultas Ilmu Sosial dan Ilmu Politik. Universitas Hasanuddin.

Fansuri, Muhammad Reza dan Fatmawati. 2018. Analisis Framing Pesan Kesalehan Sosial Pada Buku Ungkapan Hikmah Karya Komaruddin Hidayat. Jurnal AlBalagh.

Lestarysca. 2013. Konstuksi Citra Perempuan Dalam Media Online (Analisis Framing Rubrik Fashion Website Wolipop). Jurnal Kanal. Vol. 2. No. 1.

Pohan, Muhammad Munawwir. 2018. Analisis Framing Nilai Siri' Pada Sosok Zainuddin Dalam Novel Tenggelamnya Kapal Van Der Wijck. Jurnal Manajemen Pendidikan dan Keislaman.

Putra, Rizki P P. 2016. Framing Lembar Agama Islam Djaka Lodang (Analisis Framing Wiliam A. Ghamson dan Andre Modig Liani Pada Lembar Agama Islam 
Konstruksi Stigma Mistis Kota Banyuwangi...

Majalah Djaka Lodang Edisi Maret-Mei 2015). Skripsi Fakultas Ilmu Sosial dan Humaniora, UIN Sunan Kalijaga Yogyakarta. 